\title{
ENVIRONMENTAL COMPENSATION FOR PORT EXTENSION: THE CASE OF ROTTERDAM HARBOUR AND NATURE COMPENSATION, POLICY AND PRACTICE
}

\author{
F. VAN DER MEULEN \\ Frank van der Meulen Consultancy, De Ruytersingel 56, 2253 TX Voorschoten, The Netherlands \\ frank.vandermeulen@hetnet.nl
}

\begin{abstract}
The paper focuses on two aspects often forgotten when dealing with smart ports: ecology and compensation of damage. The port of Rotterdam (The Netherlands) recently built a large extension, Maasvlakte 2. It was built in an area with valuable coastal ecosystems belonging to the EU Natura 2000 network of European conservation areas. The construction and use of Maasvlakte 2 causes considerable damage to existing Natura 2000 sites. According to EU regulations, this damage should be compensated by creating new nature. In the case of Rotterdam, the compensation was twofold: a marine and a terrestrial part. The paper describes the design and the actual lay-out of the compensation works. It also reports on the monitoring that is ongoing to assess the damage to existing nature and the quality of the new (compensated) nature.
\end{abstract}

Keywords - port extension, environmental damage and compensation, EU Natura 2000, building with nature.

\section{INTRODUCTION}

The Dutch government decided in 2003 to develop a policy which enabled a new harbour extension (called Maasvlakte 2), in order to receive and handle the world's largest containerships, starting from 2015. Maasvlakte 2 (net 1000 ha, which is $20 \%$ of the already existing harbour area) was build between 2008 and 2014 by reclaiming part of the North Sea with foreshore nourishment ( $365 \mathrm{Mm} 3)$. It is expected that the new harbour will be in full operation by 2030 .

Maasvlakte 2 extends in the middle of an environment with valuable coastal and marine ecosystems. They are under protection of the EUNatura 2000 network. In such a case, EU-regulations state that construction is only allowed when there are imperative reasons of overriding public interest to carry out the plan, when there is no alternative, and when the submitter of the plan commits himself to compensate for the damage it causes. It concerns the environmental damage to Natura 2000 sites that will be caused by the new harbour and its activities.

It is important to understand that the compensation activities should start at the same time and parallel with the activities for the new harbour, and not, if at all, afterwards.

To convince possible opponents it was decided by the EU-permits to start with the compensation measures before or at least at the moment of beginning the extension.

Compensation is realized at other locations nearby the port extension (Figure 1). It involves marine ecosystems (fish, sea bottom fauna and bird communities) as well as land ecosystems (beach and dune ecosystems).

Marine compensation is necessary because the new harbour was reclaimed from the sea, causing loss of habitats and foraging areas. Beach and dune compensation was necessary because the EIA predicted that important existing dune ecosystems nearby will be damaged by the use of the new harbour (extra air pollution by more harbour traffic). In order to assess whether the predicted environmental damage indeed will occur and whether, in the future, the quality of the new nature indeed will compensate for this damage, an extensive monitoring program is running.

The case of Rotterdam is of importance to mirror with harbour development worldwide to achieve innovative smart solutions in a more sustainable way. Key concepts are compensation of irreversible damage to nature and building with nature. 


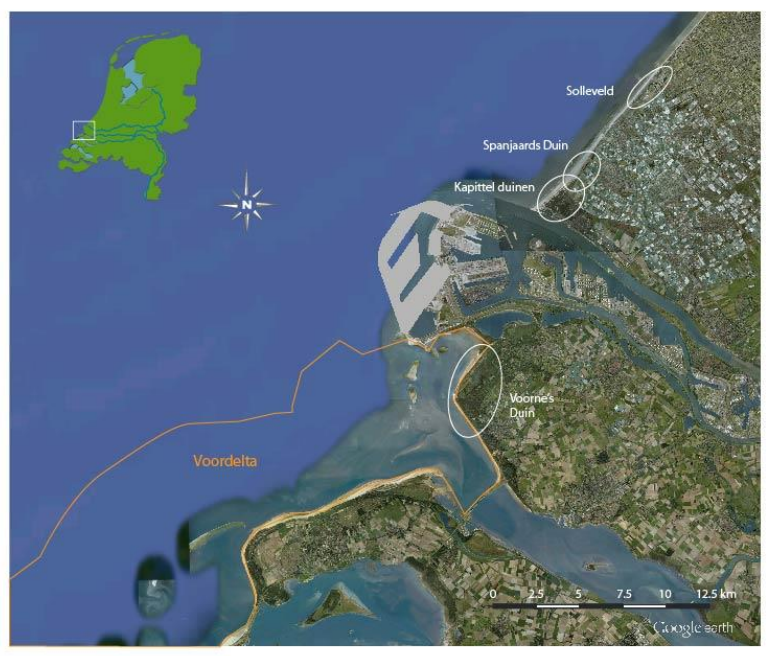

Fig .1. The Netherlands (inset) and part of the south western Delta coast of the North Sea. In the middle the new harbour extension (Maasvlakte 2) in outline. The dunes of Voorne's Duin, Kapittelduinen and Solleveld are nearby Natura 2000 areas that will suffer expected environmental damage. Spanjaards Duin, in the north, is the new dune and beach compensation area. In the south in the Voordelta (a shallow sea in front of the coast, also a Natura 2000 area) is the area where marine compensation measures are taking place (yellow boundary). Image: Google Earth..

\section{METHODOLOGY}

Monitoring of the compensation was done using the latest techniques. In the case of dune compensation: terrain morphology (GPS transects and laser altimetry), groundwater (piezometers and chemical analyses), vegetation (vegetation samples and individual species records) and in the case of marine compensation: sea bottom fauna, hyperbenthos and fish, countings of indicator sea birds, countings of trawl activities, and countings of water recreation activities.

For both compensation activities a special monitoring scheme was developed. This contains main evaluation questions with factsheets per question. Each factsheet contains sub questions, the kind of information required to answer the sub question and the strategy needed to acquire this information ${ }^{8}$

\section{- EU Natura 2000}

Natura 2000 is a network of specially protected areas, both on land and sea, in the $\mathbf{2 8}$ member states of the EU, meeting the requirements of the EUHabitat Directive. It is the largest coordinated network of protected areas in the world.

When Natura 2000 sites are predicted to be damaged by construction of a project, and the project is of outstanding national economic importance ("imperative reason of overriding public interest, without a proper alternative"), the damage needs to be compensated (article 6.3 and 6.4 of the EUHabitat Directive)(ec.europe.eu/environment/nature2000).

\section{DUNE COMPENSATION}

(project being carried out with dr Bert van der Valk, Deltares, Delft, The Netherlands)

- Damage to existing dunes and compensation targets

The EIA ${ }^{1}$ for the extension of Maasvlakte 2 predicted that the use of the new harbour would damage important dune ecosystems in the nearby existing dunes. These ecosystems belong to the EU Natura 2000 network and, under European Habitat Directive regulations, have to be compensated. They are: $\mathrm{H}$ 2190 (nutrient poor calcareous moist dune valleys, or dune slacks) and H 2130 (nutrient poor, more or less calcareous dry dunes, so-called "Grey dunes") ${ }^{2}$

In the European context, The Netherlands have a special requirement when it comes to maintaining the surface and improving the quality of these nutrient poor (N, P) dune environments. The predicted damage in existing dunes and the compensation targets in the new dunes are given in Table 1.

Table 1. Dune Compensation Targets in New Constructed Dunes of Spanjaards Duin in Relation to Predicted Losses in Existing Natura 2000 Dunes. See also Figure 2.

\begin{tabular}{|c|c|c|}
\hline $\begin{array}{c}\text { Dune compensation } \\
\text { targets }\end{array}$ & loss (ha) & $\begin{array}{l}\text { compensate } \\
\text { (ha) }\end{array}$ \\
\hline Moist dune valley (H 2190) & 1,3 & $6,5 \quad(x 5)$ \\
\hline Grey dune (H2130) & 4,2 & $9,6 \quad(x 2)$ \\
\hline $\begin{array}{l}\text { Species: Fen orchid Liparis } \\
\text { loeselii }\end{array}$ & $\begin{array}{c}1 \\
\text { population }\end{array}$ & 1 population \\
\hline $\begin{array}{l}\text { Loss of nutrient poor } \\
\text { habitats }\end{array}$ & & $\begin{array}{c}\text { Compensate } \\
\text { nutrient poor } \\
\text { habitats }\end{array}$ \\
\hline
\end{tabular}

The damage to these ecosystems occurs because the use of the new harbour will cause an increase in traffic and industrial activities. This will raise the level of NOx emissions. The extra airborne N-load will affect the nutrient household of the nutrient poor dune ecosystems. The higher nutrient level will cause some common plant species to encroach and take over the space of several rare plants that are 
characteristic of $\mathrm{H} 2190$ and $\mathrm{H} 2130$.

\section{- Dune compensation and nourishment}

In order to compensate for this loss, a new dune and beach area was constructed by beach and foreshore nourishment. The work was done in 2008 in combination with a larger regular nourishment works along the Dutch Delfland coast. The new area covers $35 \mathrm{ha}$ and involves $6,5 \times 10$ million $\mathrm{m} 3$ of sand.

The nourishment was done by dredging the sand some $19 \mathrm{~km}$ offshore and piping it onshore from a
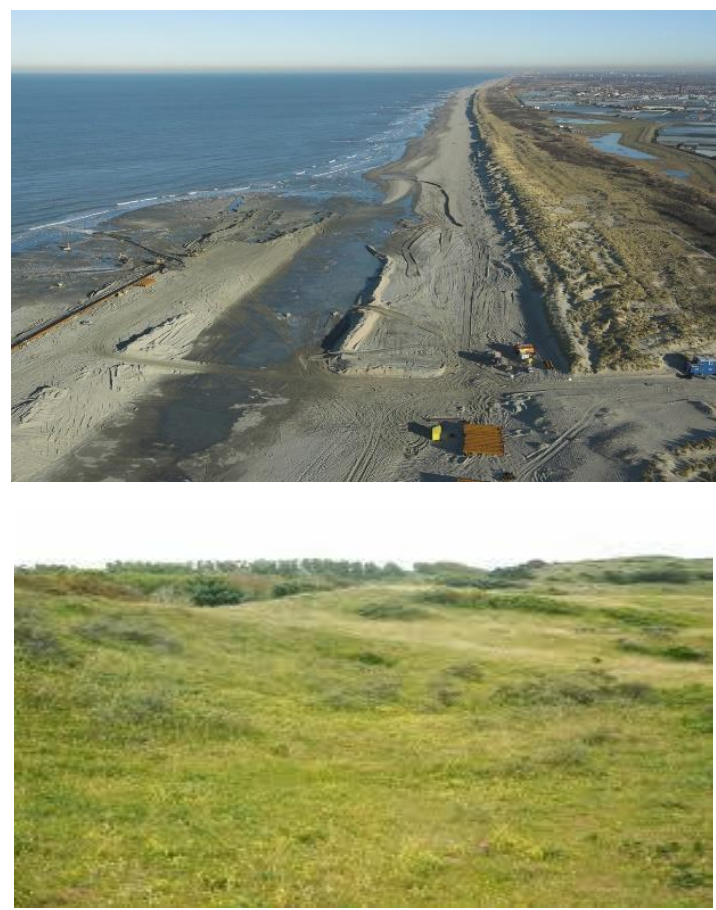

close-by connection point (Figure 1). Subsequent shovel work formed the basic shape according to its design (Fig 2): an elevated (5-7m above MSL) dry and undulating ridge, the new frontal dune, and a flat depression (ca. $2.5 \mathrm{~m}$ above MSL) or dune valley, later to become moist due to rising fresh groundwater level. Because of sand mobility (see paragraph below), part of the nourished material had to have a specific grain size $(180-250 \mu)$, which is slightly smaller than the average sea bottom sediment in front of the coast. However, earlier surveys showed that there was enough material present in the neighbourhood.
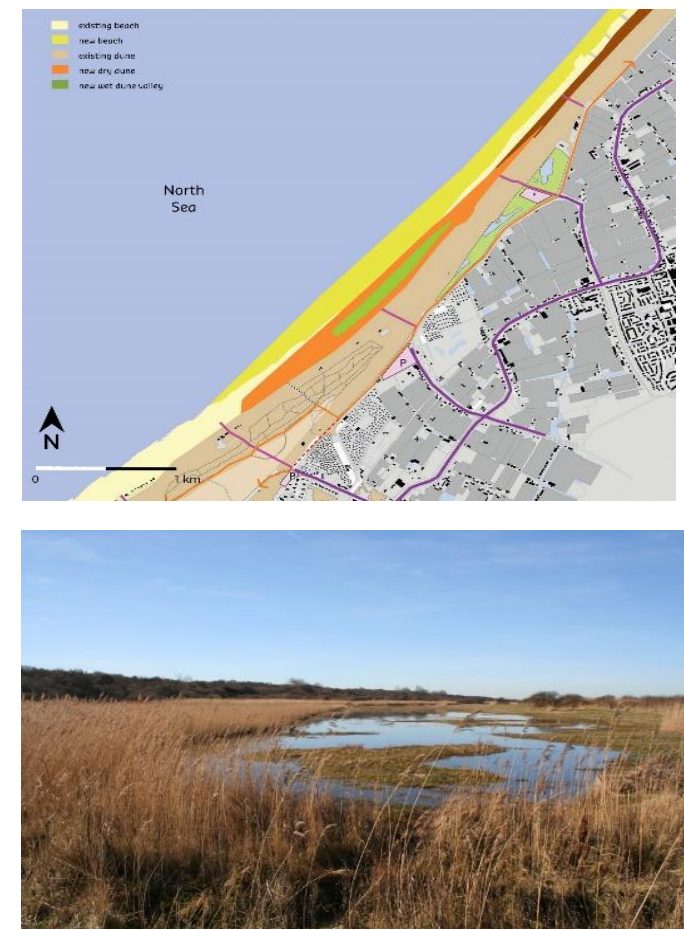

Fig .2. Top left: construction of the compensation area in front of the existing coastal fore dunes (at right) by beach and foreshore nourishment. The contours of the designed elongated moist dune valley, a flat depression, are already visible in the middle (photograph courtesy Nico Bootsma, Rijkswaterstaat). Top right: design of the new dune area in front of the Delfland coast. Grey=existing dune, yellow=new beach, orange=new dry dune, green=new moist dune valley. From Veeken et al. ${ }^{3}$ Bottom: compensation targets grey dune (left) and moist dune valley (right). The Fen orchid occurs in the latter.

\section{- Dune compensation and building with nature}

Building with nature is a technique that is being used more and more when constructing, restoring or reshaping landscapes, also at the coast. Applying this technique means that the characteristics and spontaneous forces, materials and elements of the local environment are used as much as possible ${ }^{4}$. For example, to strengthen a sandy coast with sand nourishment and not with hard materials like concrete or basalt, can be considered building with nature. In the case of the compensation area, building with nature was applied 4,5 .

\section{- Phases of new dune development}

The ecosystems that have to be compensated take time to develop. Grey dunes take $15-20$ years. A moist dune valley about five years (partly because 
of settlement of the appropriate groundwater dynamics and quality). The development of the area was foreseen in four phases (Table 2) and started from the design (Figure 2). Some phases run successively, like the development of the abiotic habitat conditions first, followed by the biotic elements.

First the basic foundation was laid out by sand nourishment. After this basic foundation, free movement of sand and spontaneous sand transport (erosion and accumulation by wind) were allowed to take place. This causes some remodelling of the basic shape and also the formation of appropriate Aeolian initial dune soils, the appropriate condition for colonisation and growth of vegetation. During this phase, the salt/brackish sand material has gradually been desalinated by precipitation; and consequently a fresh groundwater lens will develop in the subsoil, also fed by infiltration of freshwater from the (thin row of) mainland dunes (Fig 2, right). After some time (expected 4-6 years in this case), the phreatic level of this lens will rise up to the valley floor, creating habitat requirements for a moist dune valley, and, eventually, moist dune slack vegetation (H2190). Because of sand mobility, part of the nourished material had to have a specific grain size $(180-250 \mu)$, which is slightly smaller than the average sea bottom sediment in front of the coast.

Table 2. Phases of Dune Development and Building with Nature

\begin{tabular}{|c|c|}
\hline $\begin{array}{c}\text { Phases of } \\
\text { development }\end{array}$ & $\begin{array}{c}\text { Natural elements } \\
\text { and processes involved }\end{array}$ \\
\hline $\begin{array}{c}\text { Construct basic } \\
\text { foundation }\end{array}$ & $\begin{array}{c}\text { Sand that is characteristic of } \\
\text { the region }\end{array}$ \\
\hline $\begin{array}{c}\text { Remodelling of sand } \\
\text { by wind transport } \\
\text { Development of } \\
\text { appropriate } \\
\text { groundwater dynamics } \\
\text { and quality }\end{array}$ & $\begin{array}{c}\text { Building of natural dunes and } \\
\text { valleys by erosion and } \\
\text { accumulation }\end{array}$ \\
\hline $\begin{array}{c}\text { Successive } \\
\text { Desalinisation of sand by } \\
\text { precipitation }\end{array}$ \\
$\begin{array}{c}\text { and development of } \\
\text { plant (and animal) } \\
\text { communities }\end{array}$ & $\begin{array}{c}\text { Allow spontaneous, natural } \\
\text { colonisation, no active, deliberate } \\
\text { planting of dune species }\end{array}$ \\
\hline $\begin{array}{c}\text { Management to steer if } \\
\text { needed }\end{array}$ & \begin{tabular}{c} 
Aim at compensation targets \\
\hline
\end{tabular} \\
\hline
\end{tabular}

- Monitoring
In order to assess whether the dune area develops in the right direction of the target habitats, a monitoring program was established. It concerns dune geomorphology, groundwater and vegetation. Also, there are monitoring activities in the existing dunes especially concerning their nutrient $(N, P)$ status.

\section{- Overall results}

About seven years after construction, the area is still very dynamic (Figure 3). Vegetation is scarce. However, the abiotic conditions for the development of the compensation targets, the nutrient poor dune grasslands, are nearly in place. Signs of the development towards grey dunes can be seen. The area functions in a number of ways: for coastal defence, nature conservation and also recreation. In the densely populated environs of Rotterdam harbour in the Dutch Delta, this is regarded as a very positive situation. To ensure that nature development can take place, free access is not allowed. The new area is already under Natura 2000 protection.

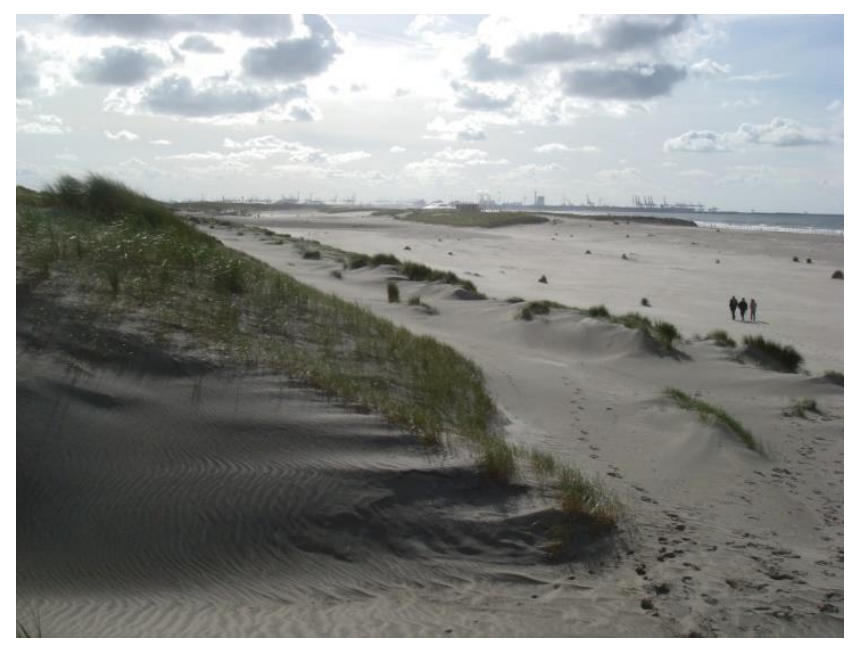

Fig .3. The new area development of Spanjaards Duin (2013). Wind activity is clearly visible. Former (existing) coastal fore dunes are to the left. New embryo dunes formed by wind and sand captured by Marram grass are in the middle. Prospective wet dune valley and new fore dune ridge are to the right. Harbour of Rotterdam (Maasvlakte 1) is in background. North Sea is (just visible) to the right.

\section{MARINE COMPENSATION}

\section{- Damage and compensation targets}

Maasvlakte 2 was reclaimed from the sea, in this case the Voordelta, a shallow marine environment of high nature value, belonging to the EU Natura 2000 network (H1110, shallow seas with sand flats permanently inundated and tidal inundations). 
Maasvlakte 2 has taken away 2,000ha of sea. Rather than creating more new sea, it was decided to improve the quality of existing waters nearby in the Voordelta with ca $10 \%$. Besides the loss of sea environment and sea (bottom) fauna (fish, benthos), there was also an expected damage to resting and foraging areas of seabirds (common scoter, sandwich tern, and common tern). These birds are most sensitive to disturbance in their habitats. In time after the construction of Maasvlakte 2, it was expected that currents will create a sea bottom pit (near the sea defense wall surrounding the harbour) of 500 ha, which also needs to be compensated.

The following marine compensation targets were set: (i) create a marine protection area of $2,500 \times 10=$ 25,000 ha in the Voordelta and within the protected area, and (ii) establish resting places for the three most sensitive seabird species, common scoter, sandwich tern and common tern (Figure 4) (Table 3).
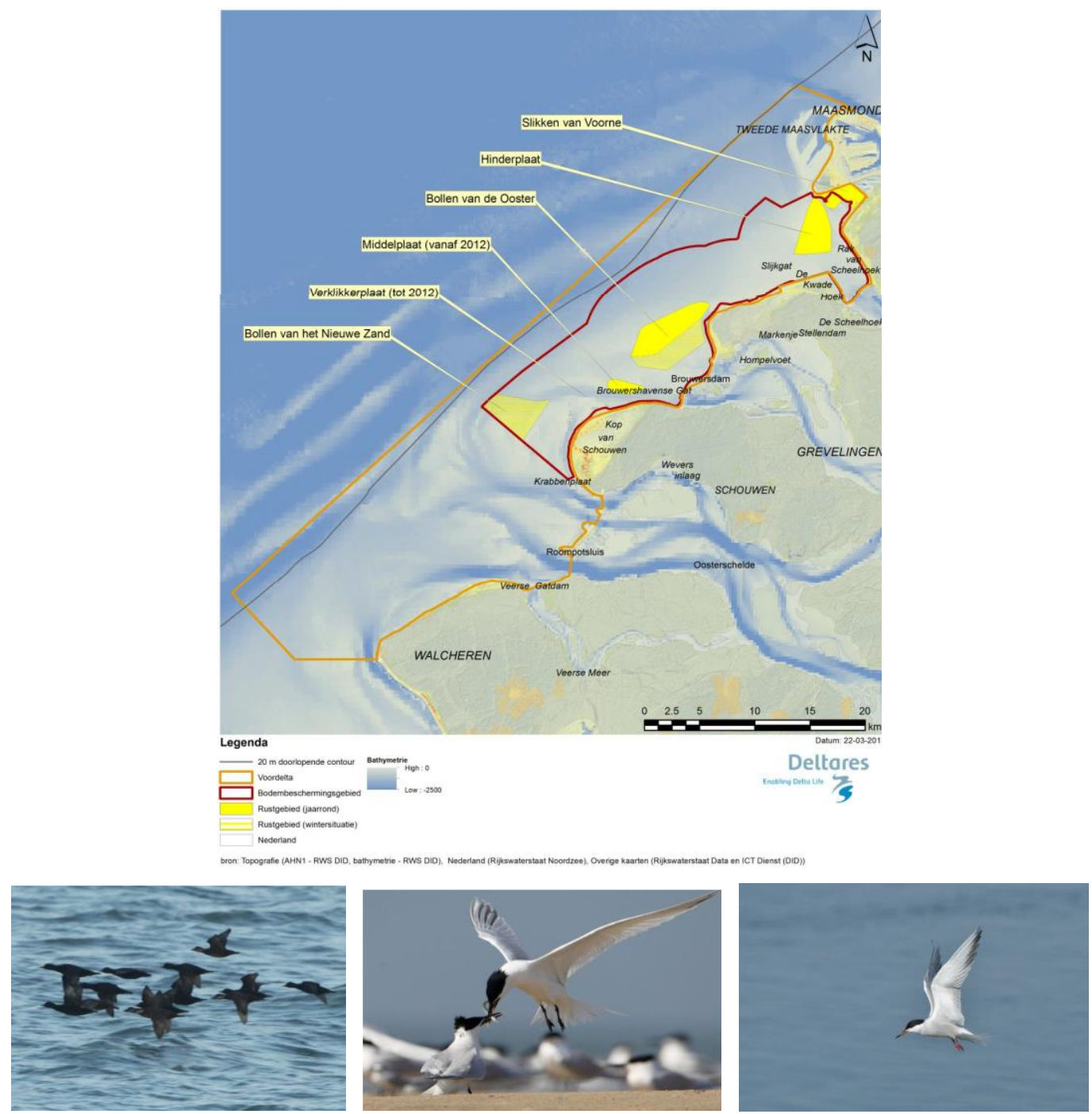

Fig .4 Top: Marine compensation in the Voordelta (orange boundaries) and the marine protection area (red) and the resting areas for seabirds (yellow). Bottom: from left to right common scoter, sandwich tern and common tern.

Table 3. Marine Damage and Compensation Targets. See Figure 4.

\begin{tabular}{|l|l|}
\hline \multicolumn{1}{|c|}{ Damage } & \multicolumn{1}{c|}{ Compensation target } \\
\hline 2,500 ha sea(bottom) lost & $\begin{array}{l}\text { Establish 25,000ha marine protection area to restore sea bottom } \\
\text { (communities) and fish. }\end{array}$ \\
\hline Resting and foraging places for seabirds lost & $\begin{array}{l}\text { Create new resting places within protection area to restore sea bird } \\
\text { populations }\end{array}$ \\
\hline
\end{tabular}




\section{- Compensation measures and monitoring 6,7}

In the protection area bottom trawling with vessels $>260 \mathrm{hp}$ were stopped. It was expected that this would improve the numbers of fish and of sea bottom fauna. And that this would favor the bird numbers because of an increase in food source. In the resting areas all human activity was banned.

Monitoring was set up to see whether the predicted damage could be sufficiently compensated. The monitoring concentrated on (i) benthos (sea bottom fauna), (ii) birds, (iii) fish, (iv) abiotics and (iv) human use of the area. The first phase $\left(T_{1}\right)$ of the monitoring period was from 2009-2013. Before this, a T0 period was monitored between 2004 and 2007. During $T_{1}$ the reference area was the Voordelta area outside the protection area.

\section{- Monitoring results}

The following results have been obtained after four years of measuring. (i). It was not possible to find a significant correlation between the stopping of fisheries activities and trends in the sea bottom. One possible reason for this is that already in 2004 fisheries activities were reduced by $80 \%$. (ii) It was not possible to find a significant correlation between numbers of the three bird species (and their spatial distribution) and the establishment of new resting places. These results are valid for comparison of the compensation areas both with the reference area and with the $\mathrm{T}_{0}$.

As a consequence, at the moment a clear sign that the damage to the marine environment is sufficiently compensated cannot yet be seen.

\section{DISCUSSION}

There are several factors that can play a role to explain the results in the Voordelta. Since the closing of the large sea inlets in this Delta area (1960-70ies) as part of the Dutch Delta Plan, this area has not yet reached its new equilibrium. Because of this and by the nature of the environment itself, the area has a high degree of hydrodynamics. There are great autonomous spatial and temporal changes in abiotic conditions of water and soil. These may cause differences in benthos and fish per time lap, which are larger than the consecutive monitoring differences.

Also, the data on numbers of birds and their spatial distribution show large differences between the years, larger than those between the compensation and the reference. In this case, also the monitoring period (four years) is too short to detect significant effects.

Another important factor is that birds and fish do not stay in the same protected area and reference area. They move to other areas and (may) come back. So, their population dynamics is influenced, not only by ecosystem changes in the area itself, but also in other areas (far away). Thus, it is difficult to attribute changes only to the compensation measures in the marine protected area.

Finally, monitoring is being done not only to assess whether the compensation is going to be sufficient, but also to understand more about the relationship between the various elements (birds, fish, benthos, nutrients, and water conditions) in this marine ecosystem.

The monitoring will continue for at least another 4year period. This will give more insight in the ecosystems itself (life strategies, carrying capacity, food chains, and resilience). It is expected that new answers can be given to evaluate the compensation efforts.

\section{CONCLUSIONS}

Large-scale technical activities for harbour extension always damage coastal nature. The EU compensation principle can contribute to restoration and new nature development and to more sustainable overall coastal solutions. Key concepts are compensation and building with nature.

Success of a project like this depends on a multidisciplinary cooperation and patience. Close cooperation between civil engineers, policy makers and ecologists is necessary.

Time should be given to nature to develop itself. This time is often longer that politicians can wait. Area protection is necessary to allow for undisturbed developments of new nature.

The case of Rotterdam harbour is of importance to mirror with harbour development worldwide. It is a case that considers, at the same time and right from the beginning, economic development and ecological quality. 


\section{ACKNOWLEDGEMENTS}

Mr Gerard van der Kolff and Mr Theo Prins (Deltares, Delft, The Netherlands), project leaders of the Marine compensation project, supplied literature and data on their project. This help is kindly acknowledged.

\section{REFERENCES}

[1] Roal Haskoning Nederland. Milieueffectrapportage (EIA) en strategische Milieubeoordeling Bestemming Maasvlakte 2. a)Hoofdrapport,b) Effectrapport. 2006. In opdracht van Projectorganisatie Maasvlakte 2. Port of Rotterdam. In Dutch.

[2] F. Meulen, B. van der, van der Valk, K., Vertegaal and M. Van Eerden. "Building with nature' at the Dutch dune coast: compensation target management in Spanjaards Duin at EU and regional policy levels." J Coast Conserv., 2015 . DOI 10.1007/s11852-014-0368-2

[3] L. Veeken, J. ter Hoeven and J. Fiselier . Ontwerpplan Duincompensatie Delflandse KustKustvisie ZuidHolland.. DHV/H+N+S/Alterra, 2007, 141 pp. In Dutch.

[4] F. Meulen, B. van der, L. van der Valk, E. Baars Schoor and $H$. van Woerden. "Development of new dunes in the Dutch Delta: nature compensation and 'building with nature." $\mathrm{J}$ Coast Conserv., 2014, DOI 10.1007/s11852-0140315-2.

[5] R.E. Waternan. Integrated coastal policy via building with nature. Opmeer Drukkerij, Den Haag, 2008.

[6] T.C. Prins, A.R. Boon, J. Reinders, C. Kuijper, G. Hendriksen, H. Holzhauer, V.T. Langenberg, J.M.A. Craeijmeersch, I.Y.M. Tulp, M.J.M. Poot, H.C.M. Seegers, J. Ademaand G.H. Van der Kolff. (2014) Monitoring natuurcompensatie Voordelta: eindrapport 1e fase 2009-2013 Deel A. Deltares rapport 1200672-000 ZKS-0042 http://kennisonline.deltares.nl/product/30731 In Dutch.

[7] Prins, T. C. and Van der Kolff, G. H. ( eds)(2014) Monitoring natuurcompensatie Voordelta: eindrapport 1e fase 2009-2013 Deel B". Deltares rapport 1200672-000-ZKS-0043, in Dutch http://kennisonline.deltares.nl/product/30737.

[8] Plan van Aanpak Meetstrategie MEP Duinen, duinen en effectivteit compensatieproject Delflandse Kust, Deltares 2009. 99pp + app In Dutch. 